\title{
PENYAKIT PERLEMAKAN HATI NON ALKOHOLIK PADA ANAK
}

\author{
Yusri Dianne Jurnalis, Delfican, Yorva Sayoeti \\ Bagian Ilmu Kesehatan Anak \\ Fakultas Kedokteran Universitas Andalas/RS. Dr. M. Djamil Padang \\ email : yusridianne@yahoo.com
}

\begin{abstract}
Abstrak
Penyakit perlemakan hati nonalkoholik (NAFLD) ditandai dengan penumpukan lemak di hati pada penderita yang tidak mengkonsumsi alkohol sebelumnya, meliputi steatosis sederhana dan steatohepatitis nonalkoholik (NASH). NAFLD/NASH merupakan manifestasi hepatik dari sindrom metabolik. Prevalensi NAFLD pada anak mengalami peningkatan seiring dengan meningkatnya prevalensi obesitas pada anak. Kelainan ini berhubungan dengan umur, jenis kelamin dan ras. Patogenesisnya diterangkan melalui hipotesis "dua pukulan". Selain manifestasi klinis, laboratorium dan pencitraan, biopsi hati merupakan baku emas dalam menegakkan diagnosis. Melalui biopsi hati dapat dinilai derajat nekroinflamatori yang terjadi serta fibrosis pada NASH. Terdapat 2 jenis steatohepatitis dengan tipe 2 ditemukan pada $51 \%$ penderita NAFLD anak. Walaupun telah dilakukan uji klinis terhadap beberapa obat, namun modifikasi gaya hidup, pola makan dan kebiasaan berolahraga merupakan tatalaksana yang banyak diterapkan saat ini.
\end{abstract}

Kata kunci : penyakit perlemakan hati nonalkoholik, steatohepatits nonalkoholik, obesitas

\begin{abstract}
Nonalcoholic fatty liver disease (NAFLD) is a disease in which excessive fat accumulates in the liver without a history of alcohol abuse. This disease includes simple steatosis and nonalcoholic steatohepatitis (NASH). NAFLD/NASH is recognized as a hepatic manifestation of metabolic syndrome. In recent years, pediatric NAFLD has increased in line with the increased prevalence of pediatric obesity. It is associated with sex, age and ethnicity. The "two-hit" hypothesis is widely accepted as the pathogenesis. Although clinical symptoms, laboratory data and imaging findings are important, liver biopsy is regarded as the gold standard of the diagnosis. It is essential for assessing the degree of necro-inflammatory change and fibrosis in NASH. Two different types of steatohepatitis have been reported, with type 2 NASH being present in as many as $51 \%$ of pediatric NAFLD patients. Although pharmacotherapy has been studied in clinical trials, lifestyle modification by diet and exercise remains the mainstay of treatment for NAFLD/NASH.
\end{abstract}

Key word: nonalcoholic fatty liver disease, nonalcoholic steatohepatitis, obesity 


\section{Pendahuluan}

Obesitas merupakan masalah kesehatan yang banyak mengenai anak dan menyebabkan gangguan kesehatan yang dapat berlangsung seumur hidup. ${ }^{(1)}$ National health and nutrition examination survey (NHANES) melaporkan 17,4 - 18,8\% anak menderita obesitas dan nantinya mereka akan menjadi dewasa yang obes pula. ${ }^{(2-}$ 4)

Penumpukan jaringan lemak dapat mengenai banyak organ sehingga anak yang obes akan berisiko tinggi untuk mengalami sindrom metabolik yang terdiri atas obesitas sentral, dislipidemia, hipertensi dan diabetes melitus (DM) tipe 2. ${ }^{(5-7)}$ Resistensi insulin memegang peranan penting dalam etiopatogenesis timbulnya berbagai macam manifestasi klinis yang sering ditemukan pada anak obes, termasuk penyakit perlemakan hati non alkoholik (nonalcoholic fatty liver disease, NAFLD). ${ }^{(1,8,9)}$

Penyakit perlemakan hati non alkoholik merupakan penyebab penyakit hati kronik pada remaja di negara barat. ${ }^{(10,11)}$ Kelainan ini pertama kali dilaporkan oleh Ludwig pada tahun 1980. ${ }^{(1,12,13)}$ Berbeda dengan penderita dewasa, maka standar diagnosis dari NAFLD pada anak belum ada. ${ }^{(5)}$ Penulisan referat ini bertujuan untuk membahas lebih lanjut mengenai patogenesis, manifestasi klinis, tatalaksana dan pencegahan penyakit perlemakan hati non alkoholik pada anak.

\section{Definisi}

Penyakit perlemakan hati non alkoholik adalah diagnosis klinikopatologis yang ditandai secara histologis dengan adanya penumpukan lemak terutama trigliserida di hepatosit dimana penyebab lain dari penyakit hati telah disingkirkan (termasuk peng- gunaan alkohol secara kronik, hepatitis $\mathrm{B}$, hepatitis $\mathrm{C}$ dan defisiensi $\alpha 1$ antitripsin). ${ }^{(5,10,14)}$ Akibat penumpukan lemak tersebut, berat hati bertambah mencapai $5 \%$ dari berat awalnya. ${ }^{(14)}$

\section{Epidemiologi}

Tominaga $\mathrm{K}$ dkk pada tahun 1995 (dikutip oleh Nobili V dkk pada tahun 2008) melaporkan prevalensi NAFLD sebesar 2,6-9,8\% pada anak dan remaja serta meningkat menjadi $77 \%$ pada anak yang obes. ${ }^{(10)}$ Berdasarkan penelitian yang dilakukan oleh Schwimmer JB dkk pada tahun 2006 didapatkan prevalensi NAFLD sebesar $38 \%$ pada anak yang obes. ${ }^{(5)}$ Selain itu juga didapatkan adanya peningkatan prevalensi sesuai dengan bertambahnya umur, yaitu $0,7 \%$ pada umur 2-4 tahun dan 17,3\% pada umur 15-19 tahun. ${ }^{5}$ Prevalensi perlemakan hati juga berbeda berdasarkan ras dan etnis dimana pada ras hispanik ditemukan sebesar $11,8 \%$, ras Asia $10,2 \%$, ras kulit putih $8,6 \%$ dan ras kulit hitam $1,5 \% .^{(5)}$

\section{Faktor risiko}

Obesitas, hiperglikemia dan hipertrigliseridemia merupakan faktor risiko yang berhubungan dengan NAFLD pada penderita dewasa dan anak. ${ }^{(6,15)}$ Walaupun sebagian besar kasus terjadi pada penderita yang berusia 50-60 tahun, namun saat ini ditemukan kecendrungan peningkatan kasus pada anak..$^{(6,11)}$

Berdasarkan penelitian yang dilakukan oleh El-Karaksy HM dkk di Mesir pada tahun 2011 didapatkan bahwa data antropometri seperti IMT, ketebalan lipatan kulit subskapula, perbandingan lingkaran perut dengan paha, gambaran ekogenisitas hati melalui pemeriksaan USG dan pemeriksaan laboratorium seperti resistensi insulin dan dislipidemia merupakan 
prediktor NASH pada anak yang obes. $^{(11)}$

Penyebab NAFLD : ${ }^{(3,14)}$

1. Primer, yaitu sindrom metabolik

2. Sekunder :

a. Nutrisional, seperti total parenteral nutrition, kehilangan berat badan yang cepat, kelaparan, pembedahan bypass pada saluran cerna.

b. Obat-obatan, seperti glukokortikoid, estrogen, tamoxifen, metotreksat, zidovudin, amiodaron, tetrasiklin intravena, didadosin, kokain, perhexilen, hipervitaminosis A, diltiazem.

c. Toksin, seperti toksin jamur (Amanita phalloides, lepiota), bahan petrokimia, fosfor, toksin Bacillus cereus.

d. Metabolik, seperti lipodistrofi, disbetalipoproteinemia, penyakit Weber-Christian, penyakit Wolman dan sindrom Reye.

e. Lain-lain, seperti inflammatory bowel disease, HIV, divertikulosis usus halus dengan pertumbuhan bakteri.

\section{Patogenesis}

Patogenesis NAFLD masih belum diketahui dengan jelas sampai sekarang. ${ }^{(16,17)}$ Day CP dan James OFW pada tahun 1999 (dikutip oleh Das SK dkk pada tahun 2006) mengusulkan hipotesis 'beberapa pukulan' dalam patogenesis NASH dimana hipotesis '2 pukulan' merupakan hipotesis yang banyak digunakan. ${ }^{18}$ Hipotesis tersebut adalah : ${ }^{(2,3,19)}$

1. 'Pukulan pertama', yaitu resistensi insulin. Resistensi insulin dapat menyebabkan terjadinya peningkatan sintesis asam lemak, peningkatan asam lemak yang dikirim ke hati, sedikit penghancuran asam lemak dan sedikit trigliserida yang dilepaskan dari hati. Akibatnya terjadi akumulasi trigliserida di hepatosit.

2. 'Pukulan kedua', yaitu stres oksidatif dan sitokin. Stres oksidatif dapat menyebabkan terjadinya peroksidasi lipid yang akan mengaktifkan sel stelata di hati serta kematian hepatosit.

\section{Diagnosis}

\section{a. Manifestasi klinis}

Penyakit perlemakan hati non alkoholik biasanya bersifat asimptomatik pada saat diagnosis ditegakkan walaupun sebagian besar penderita mengeluhkan adanya fatigue atau malaise serta rasa penuh dan tidak enak pada perut kanan atas. ${ }^{(13,19,20)}$ Pemeriksaan fisik juga biasanya masih dalam batas normal. ${ }^{(13)}$ Sekitar $56-79 \%$ penderita mengalami overweight (IMT $>25 \mathrm{~kg} / \mathrm{m}^{2}$ ) dan sepertiganya menderita sindrom metabolik. ${ }^{(16)}$ Hepatomegali biasanya merupakan satu-satunya gejala yang ditemukan dari pemeriksaan fisik. ${ }^{(19-21)}$ Pada anak dapat juga ditemukan akantosis nigrikan, yaitu pigmentasi hitam di daerah lipatan kulit atau aksila yang berhubungan dengan hiperinsulinemia. ${ }^{(17,19,20)}$ Ditemukannya manifestasi klinis dari penyakit hati kronik seperti kuning, asites, ginekomastia dan berkurangnya jumlah platelet menggambarkan penyakit yang sudah berlanjut menjadi sirosis. ${ }^{(17,21)}$

\section{b. Pemeriksaan laboratorium}

Peningkatan ringan sampai sedang dari kadar SGOT, SGPT atau keduanya merupakan abnormalitas pemeriksaan laboratorium yang banyak ditemukan dan sering merupakan satusatunya abnormalitas yang ada pada penderita NAFLD. ${ }^{(13,17,22)}$ Alkali fosfatase, $\gamma$ glutamil transferase (GGT) serum atau keduanya mengalami peningkatan pada sebagian besar penderita walaupun peningkatan 
tersebut tidak sebesar pada hepatitis alkoholik. ${ }^{(13)}$ Selain itu juga dapat ditemukan hipoalbuminemia, hiperbilirubi-nemia dan pemanjangan waktu protrombin pada penderita NAFLD yang sudah mencapai tahap sirosis. ${ }^{(17,21)}$
Indeks resistensi insulin diukur dengan menggunakan metoda homeostasis model assessment for IR (HOMA-IR) yang ditentukan dengan menggunakan rumus : ${ }^{(9)}$

HOMA-IR = kadar insulin puasa $(\mu \mathrm{IU} / \mathrm{L}) \mathrm{X}$ kadar gula darah puasa $(\mathrm{mmol} / \mathrm{L})$ 22,5

HOMA-IR $\geq 3$ dinyatakan resistensi insulin. ${ }^{(9,19)}$

\section{c. Pemeriksaan radiologi}

Pemeriksaan USG merupakan baku emas menegakkan diagnosis NAFLD, namun jarang dilakukan pada anak. ${ }^{(17)}$ Dari pemeriksaan ini dapat ditemukan adanya peningkatan ekogenisitas jaringan hati. ${ }^{(17,22)}$ Pemeriksaan ini memiliki sensitivitas $89 \%$ dan fok spesifisitas $93 \%$ dalam menentukan adanya steatosis, serta sensitivitas dan spesifisitas masing-masing $77 \%$ dan
$89 \%$ dalam menentukan adanya fibrosis. ${ }^{(17)}$ Gambar 1 berikut memperlihatkan hasil pemeriksaan USG abdomen pada penderita NAFLD.

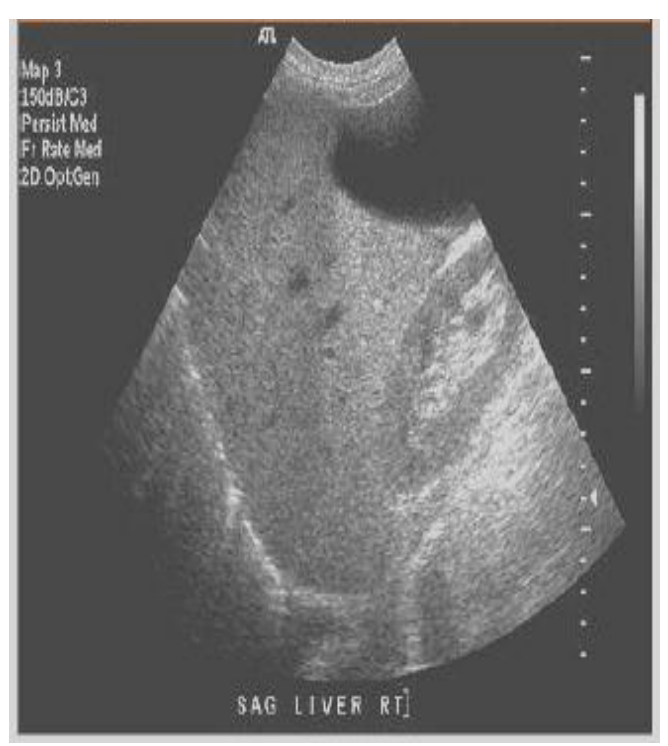

Pada pemeriksaan computed tomography scanning (CT scan) abdomen akan terlihat densitas parenkim hati yang lebih rendah. ${ }^{(17)} \mathrm{Hal}$ ini merupakan tanda adanya infiltrasi lemak ke dalam hati. ${ }^{(17)}$ Sebagian besar penderita memperlihatkan gambaran steatosis yang difus, namun dapat juga fokal pada sebagian kecil penderita. ${ }^{(17)}$ Oleh karena itu dapat terjadi salah interpretasi pada hasil pemeriksaan USG dan CT scan abdomen antara NAFLD dengan keganasan pada hati. ${ }^{(17,21)}$ Pada keadaan ini dibutuhkan pemeriksaan magnetic resonance imaging (MRI) yang dapat membedakan antara space occupying lesions (SOL) dengan infiltrasi lemak fokal (ditandai dengan adanya infiltrasi lemak pada daerah tertentu). ${ }^{(17)}$

\section{d. Pemeriksaan mikroskopis}

Biopsi hati merupakan pemeriksaan baku emas dalam menegakkan diagnosis dan menentukan prognosis penyakit, namun hanya sedikit yang merekomendasi-kannya pada penderita NAFLD. ${ }^{(11,13,24)}$ Hal ini disebabkan karena biayanya mahal dan dapat menimbulkan komplikasi akibat dari prosedurnya ataupun sedasi yang digunakan. ${ }^{(9,11,18,21)}$

Gambar 1. Pemeriksaan USG abdomen pada NAFLD. ${ }^{(23)}$ 
Peranan biopsi hati pada
NAFLD:

1. Menyingkirkan penyebab penyakit hati yang lain

2. Membedakan steatosis dengan $\mathrm{NASH}$

3. Memperkirakan prognosis berdasarkan derajat fibrosis yang ditemukan

4. Menentukan progresivitas fibrosis dari waktu ke waktu

$\operatorname{Gambaran}_{(4,23,25)}$ histologis NASH adalah: $^{(4,23,25)}$

1. Steatosis. Terdapat 2 jenis steatosis (gambar 2), yaitu mikrovesikuler (sitoplasma hepatosit diisi oleh lemak namun tidak merubah letak inti sel dan tetap berada di tengah sel) dan makrovesikuler (sitoplasma diisi oleh lemak dan inti sel telah bergeser ke pinggir).

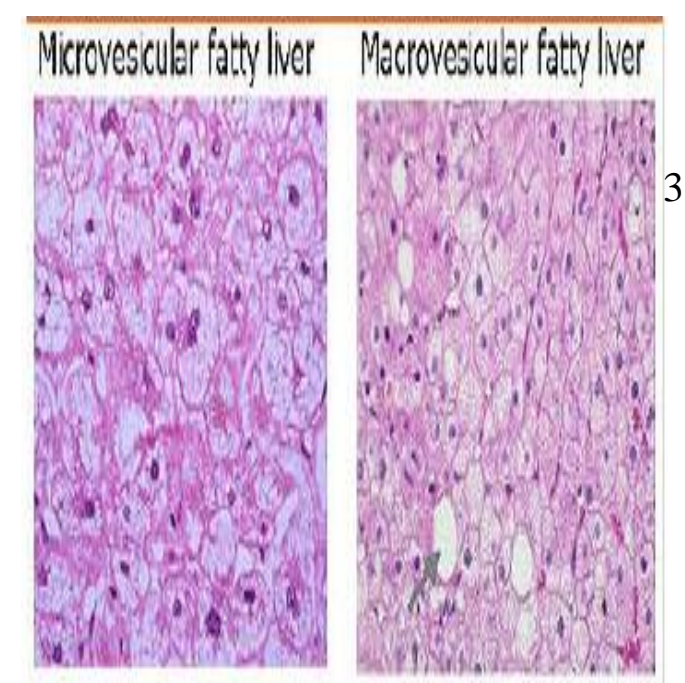

Gambar 2. Steatosis. ${ }^{(23)}$

2. Steatohepatitis, ditandai dengan adanya steatosis makrovesikuler, ballooning hepatosit, dan inflamasi merata pada lobus (gambar 3A). Selain itu juga dapat ditemukan badan Mallory di dalam ballooning hepatosit (gambar 3B)
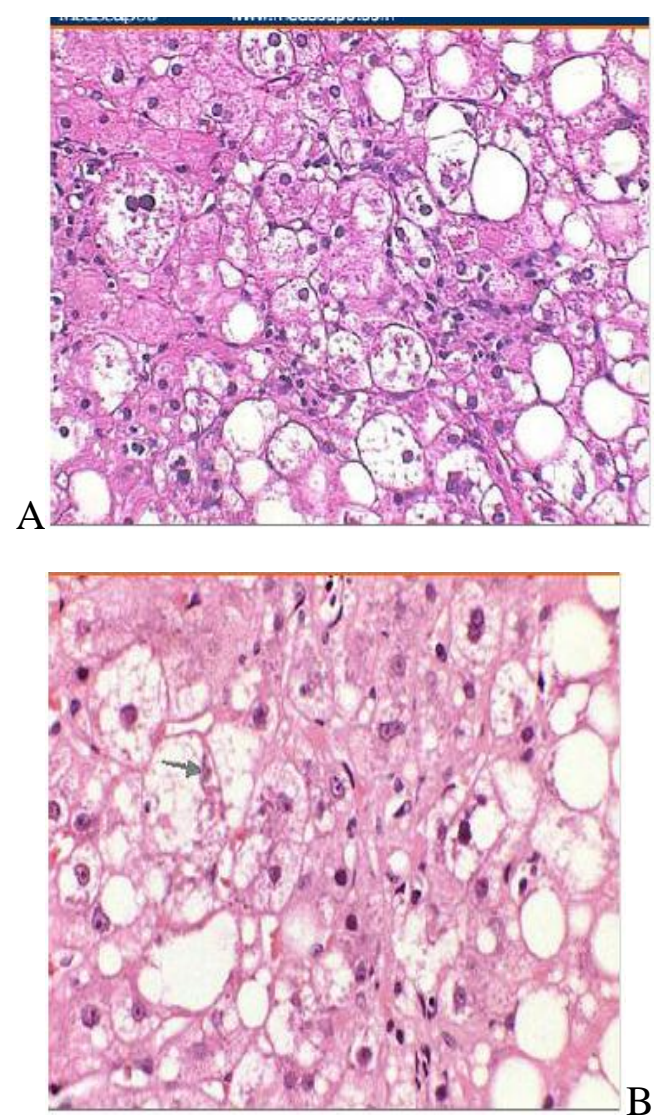

Gambar 3. Steatohepatitis. ${ }^{(23)}$

3. Steatohepatitis dengan fibrosis, diawali di periseluler dan selanjutnya membentuk jembatan jaringan fibrosis (gambar 4A)

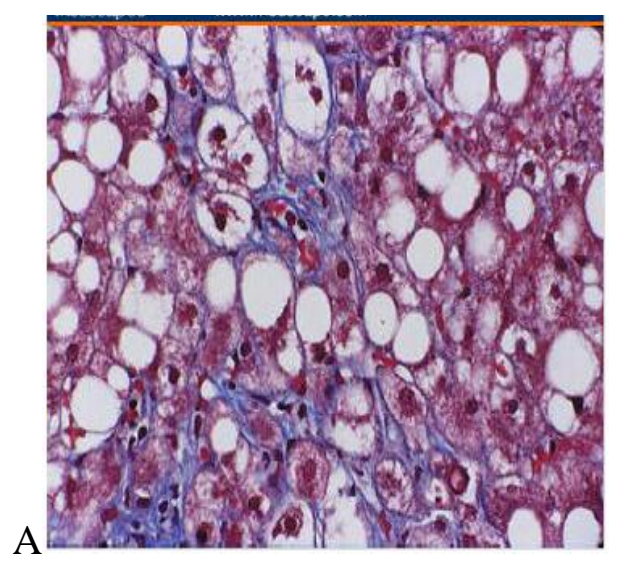




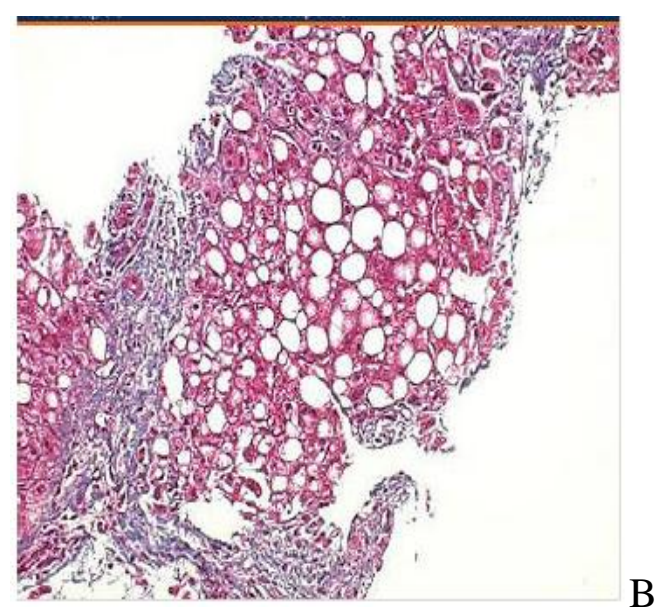

Gambar 4. Fibrosis periseluler (A) dan sirosis (B). ${ }^{(23)}$

4. Sirosis, ditandai dengan terbentuknya nodul pada jaringan hati yang dikelilingi oleh jaringan parut (gambar 4B)

Gambaran histologis dari biopsi hati berbeda antara penderita dewasa dan anak. ${ }^{(1,4,19,20)}$ Pada dewasa, Algoritme dalam menegakkan diagnosis gambaran histologisnya menyerupai NAFLD dapat dilihat pada gambar 5

hepatitis akibat pemakaian alkohol, berikut. ${ }^{13}$

yaitu degenerasi berbentuk balon, destruksi hepatosit fokal, badan Mallory dan infiltrat inflamasi yang terdiri dari leukosit polimorfonuklir. ${ }^{(1)}$ Inflamasi di daerah perivenula dan fibrosis periseluler menggambarkan suatu keadaan yang lebih berat. ${ }^{(1)}$ Pada anak tidak ditemukan degenerasi balon hepatosit dan badan Mallory. Infiltrat inflamasinya ditemukan di daerah portal serta fibrosis periselulernya sedikit, terutama terjadi di daerah portal. ${ }^{1}$

NAFLD pada anak dan remaja dikelompokkan atas 2 tipe, yaitu : ${ }^{1}$

1. Tipe 1 , ditandai dengan adanya degenerasi balon hepatosit, fibrosis perisinusoid dan steatosis, sedangkan inflamasi dan fibrosis di daerah portal tidak ditemukan.

2. Tipe 2, ditandai dengan adanya steatosis, inflamasi dan fibrosis di daerah portal, sedangkan degenerasi balon dan fibrosis persinusoid tidak ditemukan. 


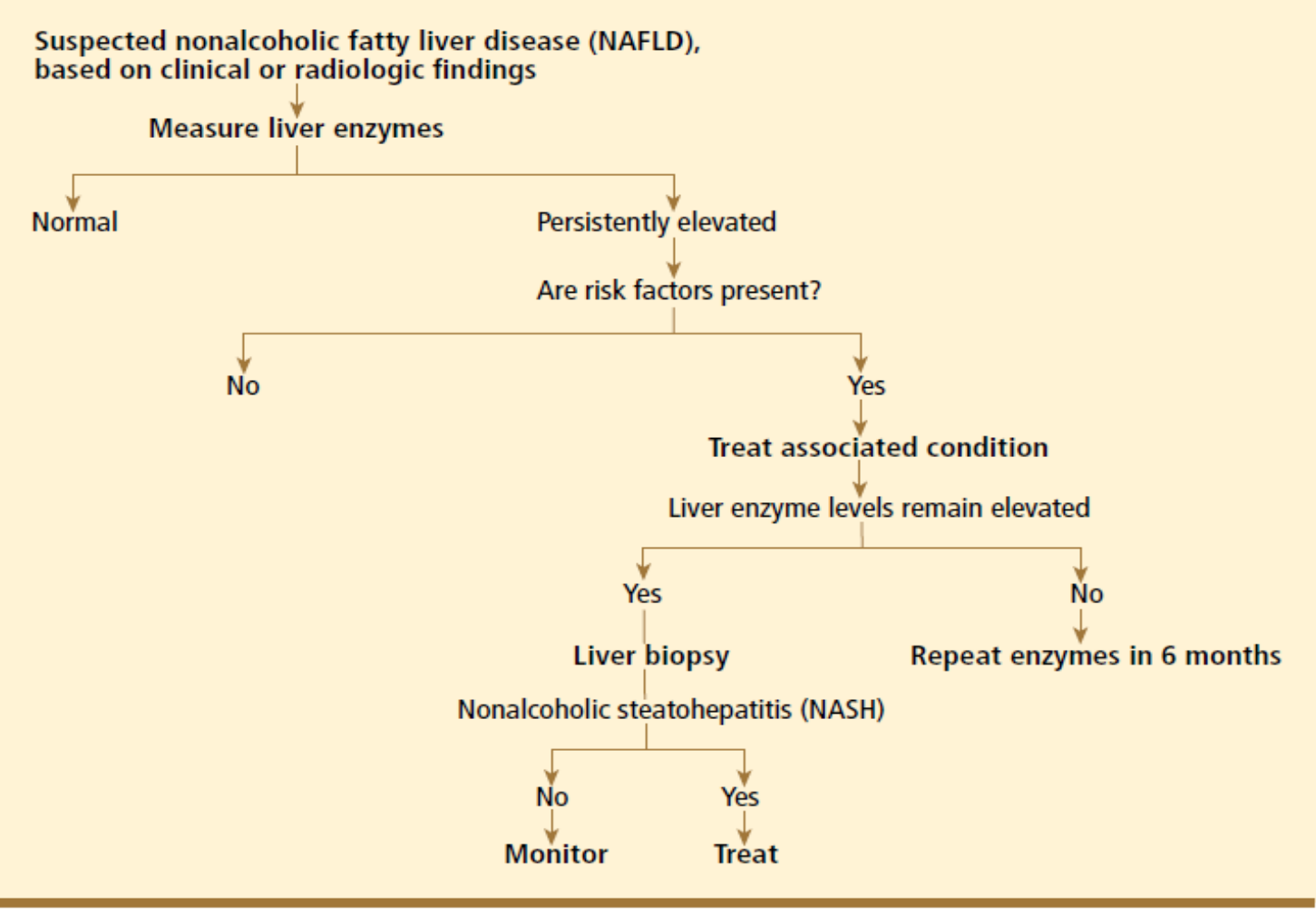

Gambar 5. Algoritme dalam diagnosis NAFLD/NASH. ${ }^{20}$

\section{Penatalaksanaan}

Sampai saat ini belum ada suatu konsensus mengenai tatalaksana NAFLD pada anak..$^{(1,2,22)}$ Prinsip utamanya adalah menurunkan berat badan dan melindungi hepatosit. ${ }^{(2)}$ Oleh karena itu terdapat 5 hal yang direkomendasikan kepada penderita, yaitu : ${ }^{(2)}$

1. Kurangi berat badan (jika penderita mengalami overweight atau obesitas)

2. Konsumsi diet yang sehat dan seimbang

3. Tingkatkan aktivitas fisik dengan berolahraga

4. Hindari pemakaian alkohol

5. Hindari pemakaian obat yang berlebihan

\section{a. Pengaturan diet dan olahraga}

Sampai saat ini penurunan berat badan melalui peningkatan aktivitas fisik merupakan satu-satunya terapi yang terbukti bermanfaat pada anak. ${ }^{(10,15,17,19) \quad \text { Penelitian yang }}$ dilakukan oleh Wang CL dkk pada tahun 2008 terhadap penderita anak mendapatkan bahwa penurunan berat badan dapat menurunkan kadar ALT, mengurangi infiltrasi lemak dan nekroinflamasi di hati, walaupun tidak ditemukan perubahan pada derajat fibrosis yang terjadi. ${ }^{(17)}$ Wang CL juga menganjurkan penurunan berat badan tidak melebihi $1 \mathrm{~kg} /$ minggu pada anak yang obes. ${ }^{(17)}$ Penurunan berat badan melebihi $5 \%$ berhubungan dengan perbaikan yang signifikan pada gambaran histologis hati. ${ }^{15}$ Program olahraga yang dianjurkan adalah yang bersifat aerobik selama 45 menit/hari. ${ }^{(10,15)}$

Berdasarkan

patogenesis NAFLD, maka diet yang diberikan sebaiknya yang bersifat low glycemic 
index karena dapat menurunkan kadar ALT serum dan mencegah terjadinya steatosis. ${ }^{(10)}$ Nobili V dkk pada tahun 2009 merekomendasikan pemberian diet hipokalorik sebesar 25-30 $\mathrm{kal} / \mathrm{kg} / \mathrm{hari}$ pada anak yang menderita overweight dan obesitas serta diet isokalorik (40-45 kal/kg/hari) pada anak dengan berat badan normal. ${ }^{(10)}$ Komposisi diet yang dianjurkan adalah karbohidrat 50-60\%, lemak 23-30\% dan protein $15-20 \% .^{(10,17)}$ Komposisi lemak yang dianjurkan adalah lemak tidak jenuh sebanyak $2 / 3$ bagian dan sisanya lemak jenuh. ${ }^{(10)}$

\section{b. Antioksidan}

Vitamin E dapat melindungi hepatosit dari kerusakan akibat radikal bebas dan hasil dari peroksidasi lipid. ${ }^{(21)}$ Pemberian vitamin E 300-1200 IU/hari selama 2-4 bulan dapat memperbaiki kadar ALT dan resistensi insulin anak dengan NASH. ${ }^{17}$

\section{c. Insulin sensitisizers}

Metformin merupakan satusatunya obat yang telah dievaluasi pemakaiannya pada anak. ${ }^{(4,10)}$ Obat ini juga aman dan efektif dalam terapi DM tipe 2 pada anak. ${ }^{(10)}$ Metformin akan mengurangi kadar glukosa plasma dengan jalan mengurangi produksi glukosa di hati melalui aktivasi AMP kinase. ${ }^{(26)}$ Aktivasi enzim ini juga akan mengurangi sintesis lipid dan meningkatkan oksidasi lemak. ${ }^{(26)}$ Manco M pada tahun 2010 menyatakan bahwa pemberian metformin dengan dosis 1,5 g/hari selama 12 bulan dapat memperbaiki kadar ALT serum pada remaja obes. ${ }^{(24)}$

\section{d. Asam ursodeoksikolat}

Asam ursodeoksikolat dapat berfungsi sebagai sitoprotektor dan antioksidan. ${ }^{(10,24)}$ Pemberian dengan dosis $10-12,5 \mathrm{mg} / \mathrm{kg} /$ hari selama 12 bulan pada anak yang menderita NASH dapat mengurangi kadar enzim hati serta memperbaiki derajat steatosis. ${ }^{(10,22,24)}$ Berdasarkan penelitian lain didapatkan bahwa pemberian asam ursodeoksikolat yang dikombinasikan dengan vitamin $\mathrm{E}$ dapat memperbaiki kadar ALT serum dan gambaran histologis hati. ${ }^{(10)}$

\section{e. Tindakan pembedahan}

Tindakan pembedahan Bariatric dapat memperbaiki NAFLD pada sebagian besar kasus. ${ }^{(15,19)}$ Selain itu Silverman EM dkk pada tahun 1995 (dikutip oleh Das SK pada tahun 2006) melaporkan bahwa tindakan gastric bypass atau gastroplasti yang dilakukan pada penderita obes secara signifikan dapat mengurangi steatosis. ${ }^{(18)}$ Nadler EP dkk pada tahun 2009 (dikutip oleh Pacifico L dkk pada tahun 2011) melaporkan adanya perbaikan fungsi hati 1-2 tahun setelah pembedahan. ${ }^{(15)}$

Transplantasi hati merupakan terapi pilihan apabila telah terjadi sirosis yang disertai dengan komplikasi seperti gagal hati. ${ }^{(16,17,25)}$ Hasil transplantasi hati pada penderita ini biasanya cukup baik walaupun ada laporan mengenai timbulnya kembali NASH pada penderita tersebut. ${ }^{(13,17,25)}$

\section{Prognosis}

Beberapa penelitian melaporkan adanya penyakit yang berlanjut menjadi sirosis pada anak dan beberapa penelitian lain melaporkan kasus NAFLD pada anak yang berlanjut menjadi sirosis pada masa remaja muda. Namun demikian, perjalanan alami dan prognosis tersebut masih belum diketahui pada penderita anak sehingga diperlukan pemantauan jangka panjang. Berdasarkan penelitian yang dilakukan oleh Feldstein dkk pada tahun 2009 didapatkan bahwa anak dengan NAFLD berisiko untuk mengalami penyakit hati stadium akhir sehingga membutuhkan tindakan transplantasi hati. ${ }^{(8)}$ 


\section{Kesimpulan}

Penyakit perlemakan hati non alkoholik adalah diagnosis klinikopatologis yang ditandai secara histologis dengan adanya penumpukan lemak di hepatosit dimana penyebab lain dari penyakit hati telah disingkirkan. Obesitas, DM tipe 2, jenis kelamin perempuan dan hiperlipidemia merupakan faktor risiko yang berhubungan dengan NAFLD.

Diagnosis NAFLD ditegakkan berdasarkan manifestasi klinis, pemeriksaan fisik dan pemeriksaan penunjang, berupa laboratorium, radiologi dan biopsi hati. Biopsi hati merupakan pemeriksaan baku emas namun jarang dilakukan karena biayanya mahal dan dapat menimbulkan komplikasi. Prinsip utama dalam tatalaksana adalah menurunkan berat badan dan melindungi hepatosit. Tatalaksana yang diberikan adalah pengaturan diet dan olahraga, pemberian antioksidan, insulin sensitisizers, asam ursodeoksikolat dan tindakan pembedahan.

\section{KEPUSTAKAAN}

1. Duarte MASM, Silva GAP. Obesity in children and adolescents: the relation between metabolic syndrome and non-alcoholic fattyliver disease. Rev. Bras. Saúde Matern. Infant. Recife 2010; 10(2):171-81.

2. Hattar LN, Wilson TA, Tabotabo LA, Smith EO, Abrams SH. Physical activity and nutrition attitudes in obese Hispanic children with non-alcoholic steatohepatitis. World J Gastroenterol 2011; 17(39): 4396-403.

3. Alisi A, Manco M, Panera N, Nobili V. Association between type two diabetes and non-alcoholic fatty liver disease in youth. Annals of Hepatology 2009;8(1):S44-50.

4. Loomba R, Sirlin CB, Schwimmer JB, Lavine JE. Advances in pediatric nonalcoholic fatty liver disease. Hepatology 2009; 50(4): 1282-93.

5. Schwimmer JB, Deutsch R, Kahen T, Lavine JE, Stanley C, Behling C. Prevalence of fatty liver in children and adolescents. Pediatics 2006;118:1388-93.

6. Sartorio A, Col AD, Agosti F, Mazzilli G, Bellentani S, Tiribelli C. Predictors of non-alcoholic fatty liver disease in obese children. Eur J Clin Nutr 2007;61:877-83.

7. Ayvaz DNC, Kilinc FN, Pac FA, Cakal E. Anthropometric measurements and body composition analysis of obese adolescents with and without metabolic syndrome. Turk $\mathrm{J}$ Med Sci 2011; 41 (2): 267-74.

8. Feldstein $\mathrm{AE}$, Charatcharoenwitthaya $P$, Treeprasertsuk S, Benson JT, Enders FB, Angulo P. The natural history of nonalcoholic fatty liver disease in children: a follow-up study for up to 20 -years. Gut 2009; 58(11): 1538-44.

9. Eminoglu TF, Camurdan OM, Oktar SO, Bideci A, Dalgic B. Factors related to non-alcoholic fatty liver disease in obese children. Turk $\mathrm{J}$ Gastroenterol 2008;19(2):85-91.

10. Nobili V, Alisi A, Raponi M. Pediatric non-alcoholic fatty liver disease : Preventive and therapeutic value of lifestyle intervention. 
World J Gastroenterol 2009;15(48):6017-22.

11. El-Karaksy HM. El-Koofi NM, Anwar GM, El-Mougy FM, ElHennawy AE, Fahmy ME. Predictors of non-alcoholic fatty liver disease in obese and overweight Egyptian children:Single center study. The Saudi Journal of Gastroenterology 2011;17(1):40-6.

12. Denzer C, Thiere D, Muche R, Koenig W, Mayer H, Kratzer W, Wabitsch M. Gender-specific prevalences of fatty liver in obese children and adolescents: roles of body fat distribution, sex steroids and insulin resistance. $\mathbf{J}$ Clin Endocrinol Metab 2009;94: 387281.

13. Kim $\mathrm{CH}, \quad$ Younossi ZM. Nonalcoholic fatty liver disease: A manifestation of the metabolic syndrome. Cleveland Clinic Journal Of Medicine 2008;7(10):721-8.

14. Angulo P. GI Epidemiology: nonalcoholic fatty liver disease. Aliment Pharmacol Ther 2007;25: 883-9.

15. Pacifico L, Nobili V, Anania C, Verdecchia P, Chiesa C. Pediatric nonalcoholic fatty liver disease, metabolic syndrome and cardiovascular risk. World J Gastroenterol 2011; 17(26): 308291.

16. Moore EA. The fight against fatty liver disease. Diakses dari www.CEwebsource.com pada tanggal 10 Januari 2012.

17. Wang CL, Liang L, Fu JF, Zou CC, Hong F, Xue JZ, Lu JR, Wu XM.
Effect of lifestyle intervention on non-alcoholic fatty liver disease in Chinese obese children. World J Gastroenterol 2008;14(10): 1598602.

18. Das SK, Mukherjee S, Vasudevan DM. Non-alcoholic fatty liver disease : an under-recognized cause with emerging importance. Current Science 2006;90(5):659-65.

19. Manco M, Bottazzo GF, DeVito R, Marcellini M, Mingrone G, Nobili V. Nonalcoholic fatty liver disease in children. Journal of the American College of Nutrition 2008; 27(6):667-76.

20. Takahashi Y, Fukusato T. Pediatric nonalcoholic fatty liver disease: Overview with emphasis on histology. World J Gastroenterol 2010; 16(42): 5280-5.

21. Malnick SDH, Knobler $H$. The medical complications of obesity. Q J Med 2006; 99:565-79.

22. Jiménez EG, Río-Valle JS, Ferre JA. Fatty liver and its clinical management in obese adolescents. Endocrinol Nutr 2011;58(1):32-7.

23. Mofrat PS, Sanyal AJ. Nonalcoholic fatty liver disease. Diunduh dari www.medscape.com pada tanggal 20 Mei 2010.

24. Manco M. Non-alcoholic fatty liver disease in children. European Endocrinology, 2010;6(1):60-3.

25. Dabhi AS, Brahmbhatt KJ, Pandya TP, Thorat PB, Shah MC. Nonalcoholic fatty liver disease (NAFLD). JIACM 2008; 9(1): 3641. 
Yusri Dianne Jurnalis, Delfican, Yorva Sayoeti, PENYAKIT PERLEMAKAN HATI 131 NON ALKOHOLIK PADA ANAK

26. Utzschneider KM, Kahn SE. disease. J Clin Endocrinol Metab Review : The role of insulin 2006;91:4753-61. resistance in nonalcoholic fatty liver 